\title{
Self-sustained catalytic combustion of carbon monoxide ignited by dielectric barrier discharge
}

\author{
Feng Bin ${ }^{\mathrm{a}}$, Xiaolin $\mathrm{Wei}^{\mathrm{a}}$, Teng $\mathrm{Li}^{\mathrm{a}, *}$, Deliang $\mathrm{Liu}^{\mathrm{b}}$, Qinglan Hao ${ }^{\mathrm{b}}$, \\ Baojuan Dou ${ }^{\mathrm{b}, * *}$ \\ ${ }^{a}$ State Key Laboratory of High-Temperature Gas Dynamics, Institute of Mechanics, Chinese Academy of Science, Beijing \\ 100190, PR China \\ ${ }^{\mathrm{b}}$ College of Marine \& Environmental Sciences, Tianjin University of Science \& Technology, Tianjin 300457, PR China
}

Received 3 December 2015; accepted 28 June 2016

Available online 14 July 2016

\begin{abstract}
This paper presents the results of a study of self-sustained catalytic combustion of $\mathrm{CO}$ ignited by dielectric barrier discharge (DBD) using $\mathrm{Ce}_{0.5} \mathrm{Zr}_{0.5} \mathrm{O}_{y} / \mathrm{TiO}_{2}(\mathrm{CeZr} / \mathrm{Ti}), \mathrm{CuZr}_{0.25} \mathrm{O}_{y} / \mathrm{TiO}_{2}(\mathrm{CuZr} / \mathrm{Ti})$, and $\mathrm{CuCe}_{0.75} \mathrm{Zr}_{0.25} \mathrm{O}_{y} / \mathrm{TiO}_{2}(\mathrm{CuCeZr} / \mathrm{Ti})$ catalysts. DBD excites and dissociates some of the reactant molecules in the gas phase. These are more easily adsorbed on the catalyst surface than are ground-state species, therefore induction begins at a lower background temperature than in thermal catalysis. $\mathrm{CO}$ is adsorbed on copper sites, therefore $\mathrm{CeZr} / \mathrm{Ti}$ is inactive in $\mathrm{CO}$ ignition, but $\mathrm{CuZr} / \mathrm{Ti}$ and $\mathrm{CuCeZr} / \mathrm{Ti}$ achieve DBD ignition at 34 and $44 \mathrm{~s}$, respectively, at a specific energy density (SED) of $1500 \mathrm{~J} / \mathrm{L}$. CO catalytic ignition by DBD involves two steps. The induction process is dominated by plasma catalysis. At the same SEDs, induction with $\mathrm{CuCeZr/Ti}$ begins earlier than those with $\mathrm{CuZr} / \mathrm{Ti}$, in good agreement with the reducibilities and oxygen-transfer properties of these catalysts. The ignition process is governed by thermal catalysis because the enhancement of external diffusion induced by increasing the temperature improves the reaction rate. $\mathrm{CuZr} / \mathrm{Ti}$ provided more $\mathrm{CO}$ adsorption sites than did $\mathrm{CuCeZr} / \mathrm{Ti}$, contributing to shortening of the ignition delay.

(C) 2016 The Combustion Institute. Published by Elsevier Inc. All rights reserved.
\end{abstract}

Keywords: Self-sustained catalytic combustion; Carbon monoxide; Ignition; Dielectric barrier discharge

\section{Introduction}

The off-gas produced during basic oxygen furnace steelmaking contains a considerable amount

* Corresponding author. Fax: +861082544222.

** Corresponding author. Fax: +86 2260600300.

E-mail addresses: Tengli@imech.ac.cn, liteng@imech.ac.cn (T. Li), bjdou@tust.edu.cn (B. Dou). of $\mathrm{CO}$. Because a high concentration of oxygen in combination with $\mathrm{CO}$ is liable to cause explosions, the off-gas generated at steelmaking intermissions is not directly recovered as a fuel, and is often discharged into the atmosphere via conventional flare burners [1]. Our new method for using this energy in $\mathrm{CO}$ catalytic oxidation is based on methane self-sustained catalytic combustion as an alternative route for electric power generation. In this process, a mixture of methane and $\mathrm{O}_{2}$ generates 
local hot spots on the catalyst surface, and then adjacent methane and $\mathrm{O}_{2}$ molecules are dissociated, leading to a thermochemical runaway reaction, followed by self-sustained non-flame burning [2]. Such a combustion strategy is suitable for portable electricity generation, because of its high combustion efficiency in small-scale devices.

Dielectric barrier discharge (DBD)-assisted ignition and oxidation processes have recently drawn attention because they give rapid start-up under cold conditions [3]. This involves strong coupling of electron-induced chemistry and thermochemistry. Discharge produces electronic excitation, dissociation, and ionization of molecules, followed by plasma chemical reactions, and the background temperature increase not only induces thermochemical reactions, but also affects the plasma physics. Zhang et al. [4] identified the contributions of the effects of plasma chemistry and thermochemistry, and confirmed that the reactant conversions depend on both two processes by independently controlling the temperature and the reactor pressure, whereas the consecutive reactions depend mainly on the temperature and the corresponding thermo-chemistry. Mintusov et al. [5] reported that the temperature increase in air- $\mathrm{C}_{2} \mathrm{H}_{4}$ flows is caused by exothermic plasma chemical oxidation, which results in ignition when the flow temperature approaches the auto-ignition temperature. Jo et al. [6] found that the ratio of the plasma power to the heating input power is an important parameter for enhancing methane oxidation. The results can be characterized by limitedness, however, due to their methodology of a high-temperature plasma source and a narrow temperature range. Although many reports have linked plasma-assisted ignition of air-fuel flows, no statistical evidence of plasmaassisted catalytic ignition to achieve self-sustained combustion has yet been presented.

Our previous study showed that $\mathrm{CuCe}_{0.75}$ $\mathrm{Zr}_{0.25} \mathrm{O}_{y}$ mixed oxides formed on ZSM-5 substrates show excellent catalytic activities because copper-ceria synergism improves the redox capability and the ceria-zirconium solid solution has a good oxygen storage capacity [7]. In this work, we achieved $\mathrm{CO}$ self-sustained combustion ignited by $\mathrm{DBD}$ for the first time, using $\mathrm{CuCe}_{0.75}$ $\mathrm{Zr}_{0.25} \mathrm{O}_{y} / \mathrm{TiO}_{2} \quad(\mathrm{CuCeZr} / \mathrm{Ti}), \quad \mathrm{CuZr}_{0.25} \mathrm{O}_{y} / \mathrm{TiO}_{2}$ (CuZr/Ti), and $\mathrm{Ce}_{0.75} \mathrm{Zr}_{0.25} \mathrm{O}_{y} / \mathrm{TiO}_{2}(\mathrm{CeZr} / \mathrm{Ti})$ catalysts with $\mathrm{Cu}: \mathrm{Ce}: \mathrm{Zr}$ molar ratios of 1:0.75:0.25. Inert $\mathrm{TiO}_{2}$ was used as the substrate because of its excellent thermal stability and good dispersion of active species. The promotion of active phase dispersion, oxygen mobility, and redox properties caused by strong interactions among copper, cerium, and zirconium species will be discussed. We distinguished between the effects of electroninduced chemistry and thermochemistry by using DBD and temperature-programmed ignition (TPI), combined with various characterization techniques. The results obtained will be helpful in introducing the use of plasma-assisted ignition for self-sustained catalytic combustion of $\mathrm{CO}$ in steelmaking off-gas.

\section{Experimental specifications}

\subsection{Synthesis of catalysts}

The $\mathrm{TiO}_{2}$ support was pure anatase $\mathrm{TiO}_{2}$ (Degussa). The $\mathrm{CuCeZr} / \mathrm{Ti}, \mathrm{CuZr} / \mathrm{Ti}$, and $\mathrm{CeZr} / \mathrm{Ti}$ catalysts were prepared using an incipient wetness impregnation method. The $\mathrm{TiO}_{2}$ gel support was impregnated with an aqueous solution containing appropriate amounts of copper, zirconium, and cerium nitrates. The catalysts were dried for $8 \mathrm{~h}$ at $120^{\circ} \mathrm{C}$ and calcined in air for $6 \mathrm{~h}$ at $600^{\circ} \mathrm{C}$. The dried samples were crushed and sieved to 10-12 mesh. The copper content of the $\mathrm{CuCeZr} / \mathrm{Ti}$ catalyst was fixed at $4 \mathrm{wt} \%$ and the molar ratio of $\mathrm{Cu}: \mathrm{Ce}: \mathrm{Zr}$ was 1:0.75:0.25. For the $\mathrm{CuZr} / \mathrm{Ti}$ and $\mathrm{CeZr} / \mathrm{Ti}$ catalysts, the molar ratios of $\mathrm{Cu}: \mathrm{Zr}$ and $\mathrm{Ce}: \mathrm{Zr}$ were $1: 0.25$ and $0.75: 0.25$, respectively.

\subsection{Characterization}

X-ray photoelectron spectroscopy (XPS) was performed using a Kratos Axis Ultra DLD spectrometer with a $\mathrm{Mg} \mathrm{K} \alpha \mathrm{X}$-ray source. Temperatureprogrammed $\mathrm{H}_{2}$ reduction $\left(\mathrm{H}_{2}-\mathrm{TPR}\right)$ experiments were performed using a Micromeritics 2920 II instrument with $5 \% \mathrm{H}_{2} / \mathrm{Ar}$ at a heating rate of $15^{\circ} \mathrm{C} / \mathrm{min}$ to $600^{\circ} \mathrm{C}$. Prior to reduction, the sample (ca. $200 \mathrm{mg}$ ) was pretreated in flowing $\mathrm{Ar}$ at $300^{\circ} \mathrm{C}$ for $1 \mathrm{~h}$. Temperature-programmed $\mathrm{O}_{2}$ desorption $\left(\mathrm{O}_{2}\right.$-TPD) was also performed with the Micromeritics 2920 II instrument using $200 \mathrm{mg}$ of sample. After $\mathrm{O}_{2}(30 \mathrm{~mL} / \mathrm{min})$ saturation for $1 \mathrm{~h}$, the gas was switched to $\operatorname{Ar}$ for $0.5 \mathrm{~h}$, and TPD was performed by ramping the temperature at $10^{\circ} \mathrm{C} / \mathrm{min}$ to $600^{\circ} \mathrm{C}$ in $\operatorname{Ar}(30 \mathrm{~mL} / \mathrm{min})$. Desorption of $\mathrm{O}_{2}$ was detected using a thermal conductivity detector. In situ diffuse-reflectance infrared Fouriertransform (DRIFT) spectroscopy was performed using a Bruker Tensor 27 spectrophotometer. Selfsupporting disks prepared from the sample powders were suspended in a quartz holder and then mounted in an IR cell (Tianjin XianQuan Industry and Trade Development CO., Ltd.) connected to a vacuum line. The disks were heated at $300^{\circ} \mathrm{C}$ in $\mathrm{N}_{2}$ for $1 \mathrm{~h}$ and evacuated to a pressure of $3 \times 10^{-3} \mathrm{mbar}$ for $1 \mathrm{~h}$. The IR CO adsorption measurements were performed at $\mathrm{CO}$ pressures of about 20 Torr with the samples at room temperature. After exposure to $\mathrm{CO}$, IR spectra were recorded at $30 \mathrm{~s}$ intervals until the spectrum was stable.

\subsection{Experimental setup}

Figure 1 shows a schematic diagram of the experimental setup. The system consisted of a continuous flow gas-supply system, electric furnace, 


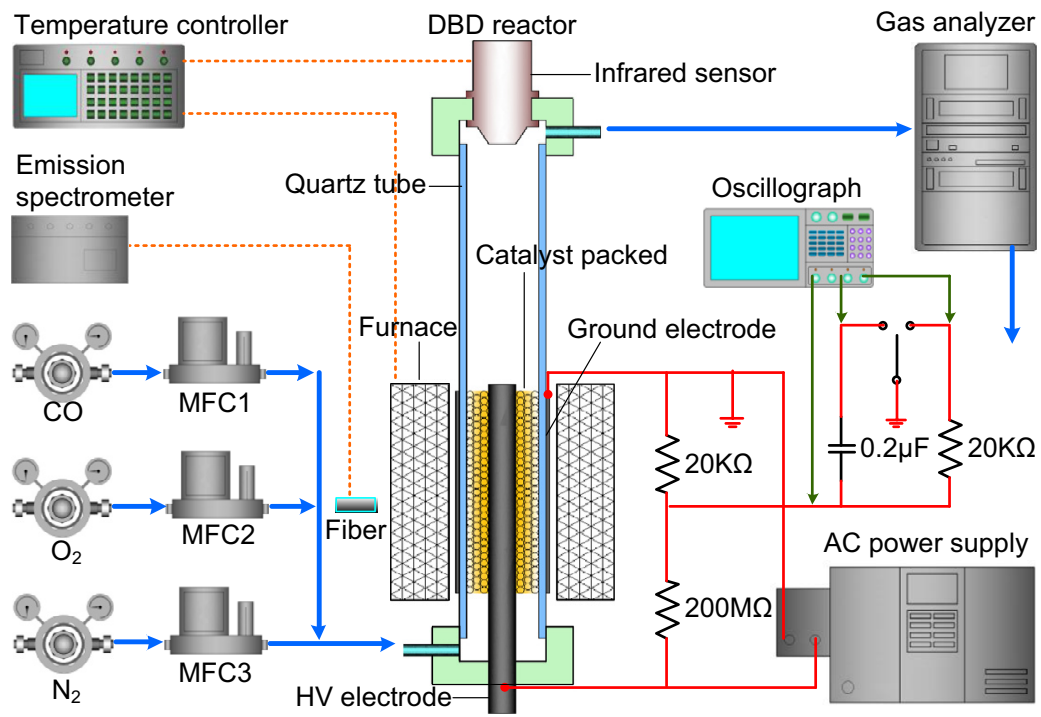

Fig. 1. Schematic diagram of experimental setup.

electric and gaseous analytical systems, AC power supply (1-50 kHz, $0-30 \mathrm{kV}$, sine wave), and a DBD reactor. The feed gas contained $15 \% \mathrm{CO}$ and balance $15 \% \mathrm{O}_{2} / \mathrm{N}_{2}$, and the flow rate was $3 \mathrm{~L} / \mathrm{min}$. An online gas analyzer (Maihak) was used to monitor the effluent $\mathrm{CO}, \mathrm{O}_{2}, \mathrm{NO}_{x}$, and $\mathrm{CO}_{2}$.

The plasma was generated in a tubular quartz reactor of inner diameter $15 \mathrm{~mm}$ and wall thickness $1.5 \mathrm{~mm}$, which acted as a dielectric and separated the inner and outer electrodes. A ceriumtungsten rod of diameter $8 \mathrm{~mm}$ was selected as the inner electrode, which was connected to a high voltage and placed on the axis of the reactor. Steelwire netting (length $5 \mathrm{~cm}$ ) was wrapped around the outer surface of the quartz as the grounding electrode. A plasma zone was created between the inner electrode and the dielectric, which was packed with catalyst. An emission spectrometer (USB2500 PLUS, Ocean Optics) connected by an optical fiber to an optical access facility was used to identify the reactive species generated during DBD. The distance between the optical fiber and the discharge zone was about $5 \mathrm{~mm}$. The catalyst background temperature during discharge was measured using an IR temperature sensor along the inner axis. Before TPI was performed by ramping the temperature at $10^{\circ} \mathrm{C} / \mathrm{min}$, the quartz reactor was mounted in a tube furnace and the reaction temperature was controlled based on the measurements made by the IR temperature sensor.

Electrical discharge measurements were performed using a digital oscilloscope (Tektronix, TDS1102). The applied voltage was determined using a 10,000:1 divider resistor connected in parallel with the discharge circuit, and the current was obtained from the voltage drop across a $20 \mathrm{k} \Omega$ sam- pling resistor connected in series with the ground electrode of the DBD reactor. The consumed energy and capacitance of the adjacent dielectric barrier were estimated from voltage-charge Lissajous figures, using a $0.2 \mu \mathrm{F}$ non-inductive capacitor inserted between the reactor and the ground instead of the sampling resistor [8]. The specific energy density (SED) was calculated as the consumed energy divided by the total flow rate.

\section{Results and discussion}

\subsection{XPS analysis}

The chemical states and surface compositions of the catalysts were investigated using XPS. The $\mathrm{Cu} 2 \mathrm{p}$ spectra (Fig. 2a) for the $\mathrm{CuCeZr/Ti}$ and $\mathrm{CuZr} / \mathrm{Ti}$ catalysts show two main peaks, for $\mathrm{Cu}$ $2 \mathrm{p}_{3 / 2}$ and $\mathrm{Cu} 2 \mathrm{p}_{1 / 2}$, at about 933.0 and $953.8 \mathrm{eV}$, respectively. The shake-up peaks located in the range 938.1-947.7 eV confirm the presence of divalent copper. Peak deconvolution and fitting split the $\mathrm{Cu}$ $2 \mathrm{p}_{3 / 2}$ peak into two peaks, at 932.6 and $934.4 \mathrm{eV}$, corresponding to $\mathrm{Cu}^{+}$and $\mathrm{Cu}^{2+}$ ions, respectively. The Ce 3d spectra of the catalysts (Fig. 2b) were individually deconvoluted into $3 \mathrm{~d}_{5 / 2}$ and $3 \mathrm{~d}_{3 / 2}$ spinorbit components (labeled $v$ and $u$, respectively), which arise from $\mathrm{Ce}^{4+} \leftrightarrow \mathrm{Ce}^{3+}$ electronic transitions. The main chemical valence of cerium in the $\mathrm{CuCeZr} / \mathrm{Ti}$ and $\mathrm{CeZr} / \mathrm{Ti}$ catalysts is $+4\left(v, v_{2}, v_{3}, u\right.$, $u_{2}$, and $\left.u_{3}\right)$, but a small quantity of $\mathrm{Ce}^{3+}\left(v_{1}\right.$ and $u_{1}$ ) is also present (Table 1). Enhancement of the homogeneities of the cerium and zirconium atoms promotes the $\mathrm{Ce}^{4+} \rightarrow \mathrm{Ce}^{3+}$ valence change, because of substitution of $\mathrm{Ce}^{4+}$ by $\mathrm{Zr}^{4+}$ during calcination. 
Table 1

Surface atomic ratios of catalysts obtained from XPS analysis. The bulk atomic ratios are listed in the bracket.

\begin{tabular}{lllll}
\hline Sample & $\mathrm{Cu} / \mathrm{Ti}$ & $\mathrm{Cu}^{2+} / \mathrm{Cu}^{+}$ & $\mathrm{Ce} / \mathrm{Ti}$ & $\mathrm{Ce}^{3+} / \mathrm{Ce}^{4+}$ \\
\hline $\mathrm{CuCeZr} / \mathrm{Ti}$ & $0.235(0.059)$ & 1.68 & $0.082(0.044)$ & 0.319 \\
$\mathrm{CuZr} / \mathrm{Ti}$ & $0.224(0.055)$ & 2.06 & $/$ & $/$ \\
$\mathrm{CeZr} / \mathrm{Ti}$ & $/$ & $I$ & $0.104(0.042)$ & 0.758 \\
\hline
\end{tabular}

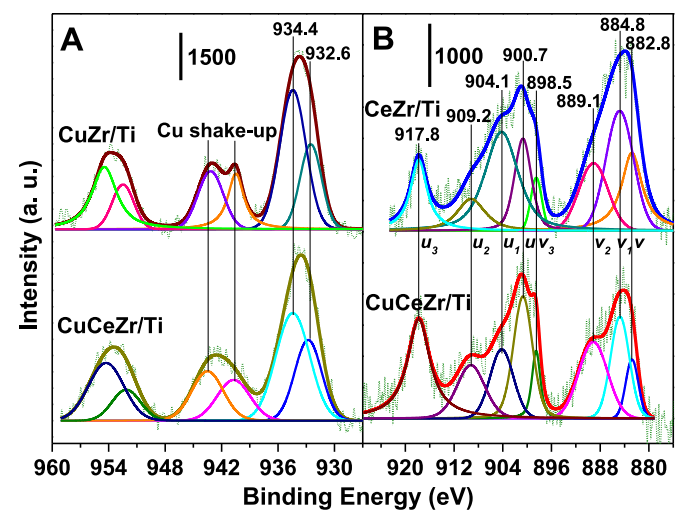

Fig. 2. Narrow $\mathrm{Cu} 2 \mathrm{p}$ (A) and Ce 3d (B) XP spectra of catalysts.

The surface composition atomic ratios of $\mathrm{Cu} / \mathrm{Ti}$ and $\mathrm{Ce} / \mathrm{Ti}$ determined using XPS are presented in Table 1 along with the corresponding bulk ratios listed in parentheses. The ratios obtained using XPS are about four times higher than the corresponding bulk values, indicating that copper and cerium tend to migrate to the surfaces of $\mathrm{TiO}_{2}$ grains. The $\mathrm{Cu}^{2+} / \mathrm{Cu}^{+}$ratio decreases significantly from 2.06 for $\mathrm{CuZr} / \mathrm{Ti}$ to 1.68 for $\mathrm{CuCeZr} / \mathrm{Ti}$. This result is in agreement with those reported by Gaudin et al. [9] and indicates that the presence of cerium oxide favors the formation of $\mathrm{Cu}^{+}$species. Quantitative data give $\mathrm{Ce}^{3+} / \mathrm{Ce}^{4+}$ ratios of 0.319 for $\mathrm{CuCeZr} / \mathrm{Ti}$ and 0.758 for $\mathrm{CeZr} / \mathrm{Ti}$. The presence of $\mathrm{Ce}^{3+}$ in the catalysts favors the formation of vacancies and unsaturated chemical bonds on the surface, resulting in increased oxygen adsorption [10].

\section{2. $\mathrm{H}_{2}-T P R$ analysis}

The redox properties of the catalysts were investigated using $\mathrm{H}_{2}-\mathrm{TPR}$. Figure 3 shows that $\mathrm{CeZr} / \mathrm{Ti}$ does not give distinct reduction peaks in the range $50-400{ }^{\circ} \mathrm{C}$ and undergoes reduction with two temperature maxima, at 643 and $807^{\circ} \mathrm{C}$, arising from reduction of surface $\mathrm{Ce}^{4+}$ ions. In the cases of $\mathrm{CuZr} / \mathrm{Ti}$ and $\mathrm{CuCeZr} / \mathrm{Ti}$, three reduction peaks, at $154-180\left(\alpha-\mathrm{H}_{2}\right), 263-279\left(\beta-\mathrm{H}_{2}\right)$, and 314-317 ${ }^{\circ} \mathrm{C}\left(\gamma-\mathrm{H}_{2}\right)$, are observed in the TPR profiles. The $\alpha$ and $\beta$ peaks are associated with small and medium-sized $\mathrm{CuO}$ particles, which are highly dispersed on the catalyst surface and

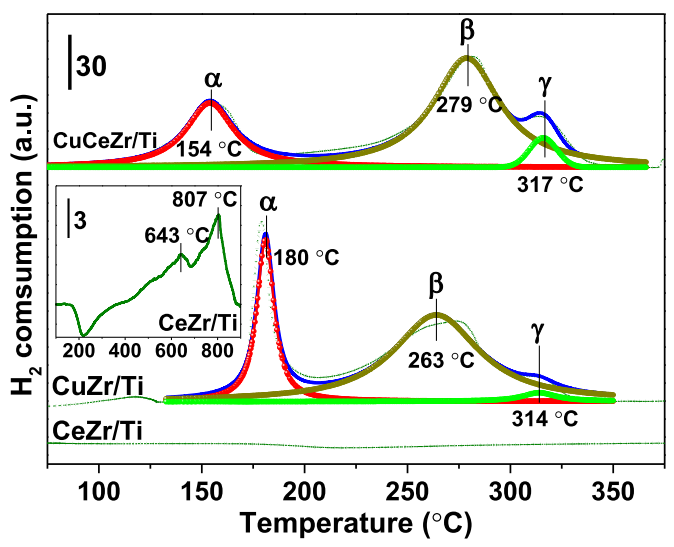

Fig. 3. $\mathrm{H}_{2}-\mathrm{TPR}$ profiles of catalysts.

have reduction temperatures significantly lower than that of bulk $\mathrm{CuO}(\gamma$ peak). For $\mathrm{CuZr} / \mathrm{Ti}$, the $\alpha$ peak appears within a narrow temperature range $\left(160-210^{\circ} \mathrm{C}\right)$, because of local temperature runaway. This observation is in accordance with the high $\mathrm{Cu}^{2+} / \mathrm{Cu}^{+}$ratio for $\mathrm{CuZr} / \mathrm{Ti}$ detected by XPS. The position of the $\alpha$ peak shifts to lower temperature for $\mathrm{CuCeZr} / \mathrm{Ti}$, and those of the $\beta$ and $\gamma$ peaks shift to higher ones. The $\beta$ and $\gamma$ peak shifts clearly result from the growth of small and medium-sized $\mathrm{CuO}$ particles after cerium addition. The $\alpha$ peak shift suggests enhanced catalyst reducibility and can be correlated with structural changes in the catalyst, because copper species preferentially interact with ceria to form $\mathrm{Cu}-\mathrm{Ce}$ solid solutions. The total amount of $\mathrm{H}_{2}$ consumed during a $\mathrm{H}_{2}$-TPR run was $42.2 \mu \mathrm{mol} / \mathrm{g}$ for $\mathrm{CuCeZr} / \mathrm{Ti}$, i.e., higher than that of $39.6 \mu \mathrm{mol} / \mathrm{g}$ for $\mathrm{CuZr} / \mathrm{Ti}$. It is probable that some copper ions enter the ceria lattice, and this increases the oxygen mobility and enables easy reduction of copper [11].

\subsection{CO adsorption at room temperature}

DRIFT spectra of $\mathrm{CO}$ adsorbed on the catalysts are shown in Fig. 4. There is no $\mathrm{CO}$ chemisorption peak in the region $2200-2000 \mathrm{~cm}^{-1}$ for CeZr/Ti, but there is a faint band at $2144 \mathrm{~cm}^{-1}$ corresponding to weak physisorption. The strong band at $2109 \mathrm{~cm}^{-1}$ for the $\mathrm{CuCeZr} / \mathrm{Ti}$ and $\mathrm{CuZr} / \mathrm{Ti}$ catalysts is assigned to $\mathrm{CO}$ adsorption at copper sites to form $\mathrm{Cu}^{+}$-carbonyls, because the $\mathrm{d}$ orbitals of copper 


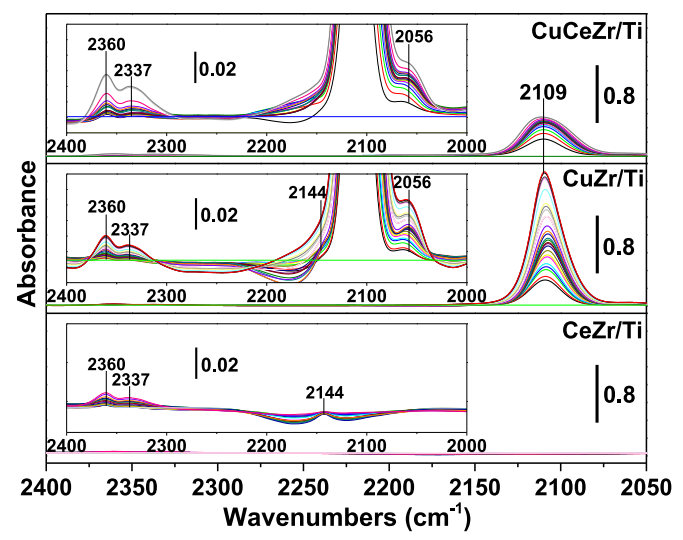

Fig. 4. DRIFT spectra of CO adsorbed on catalysts.

ions are completely or nearly full, and can form strong bonds with $\mathrm{CO}$. The cerium ions, however, with the outer shell electron distributions of $4 \mathrm{f} 1$ and 5S2 4d10 5P6, respectively, are difficult to offer electrons from d-orbitals to the anti-bonding $\pi$-orbitals. The affinity between cerium and CO is therefore weak. Such chemisorption giving rise to $\mathrm{Cu}^{+}$-carbonyl species would occur when $\mathrm{Cu}^{2+}$ species (insert toward $\mathrm{CO}$ adsorption) are automatically reduced to $\mathrm{Cu}^{+}$in the starting catalysts [12].

A comparison of the DRIFT spectra of $\mathrm{CuCeZr} / \mathrm{Ti}$ and $\mathrm{CuZr} / \mathrm{Ti}$ shows that the intensity of the $\mathrm{Cu}^{+}$-carbonyl band for $\mathrm{CuZr} / \mathrm{Ti}$ is significantly higher than that for $\mathrm{CuCeZr} / \mathrm{Ti}$, which is in accordance with the $\mathrm{Cu}^{2+} / \mathrm{Cu}^{+}$ratio of $\mathrm{CuZr} / \mathrm{Ti}$ being higher than that of $\mathrm{CuCeZr} / \mathrm{Ti}$, as shown by XPS. The weak band at $2056 \mathrm{~cm}^{-1}$ is assigned to $\mathrm{CO}$ linearly adsorbed on $\mathrm{Cu}^{0}$, which is unstable and does not contribute to $\mathrm{CO}$ oxidation. $\mathrm{CO}_{2}$ signals at 2337 and $2360 \mathrm{~cm}^{-1}$ can also be monitored. The faint reaction between $\mathrm{Cu}^{+}$-carbonyls and lattice oxygen in the catalysts at room temperature explain this behavior.

\subsection{Temperature-programmed $\mathrm{O}_{2}$ desorption}

$\mathrm{O}_{2}$-TPD tests were performed to confirm oxygen activation over the catalysts. Figure 5 shows that $\mathrm{CuZr} / \mathrm{Ti}$ and $\mathrm{CuCeZr} / \mathrm{Ti}$ give $\alpha$ and $\beta$ desorption peaks, but $\mathrm{CeZr} / \mathrm{Ti}$ gives only a $\beta$ desorption peak. Considering the low desorption temperature $\left(<350^{\circ} \mathrm{C}\right)$, the active oxygen species are probably $\mathrm{O}_{2}{ }^{-}$[13]. The lower-temperature $\alpha$-oxygen desorption can be related to copper species dispersed on the catalyst surface, whereas $\beta$-oxygen desorption results from copper- and/or cerium-impregnated $\mathrm{ZrO}_{2}$. The Ce 3d XP spectra show that oxygen vacancies are present in the cerium-containing catalysts, therefore the formation of $\alpha$-oxygen species in $\mathrm{CuCeZr} / \mathrm{Ti}$ via oxygen vacancies in coppercerium mixed oxides is plausible. The larger peak area and lower desorption peak temperature for

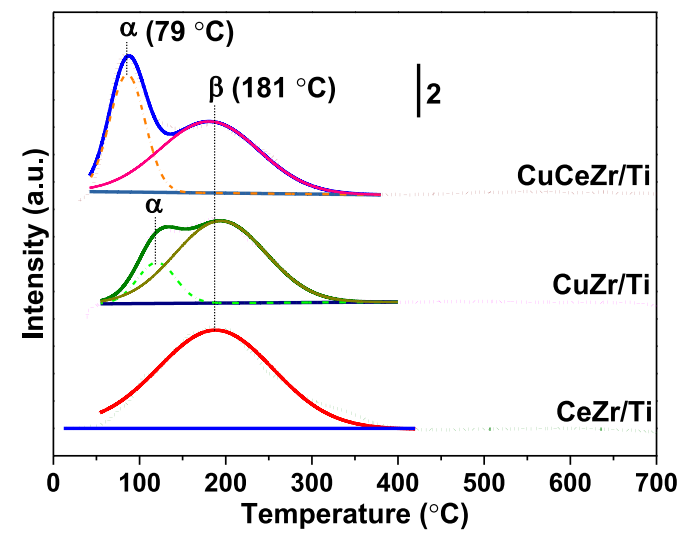

Fig. 5. $\mathrm{O}_{2}$-TPD profiles of catalysts.

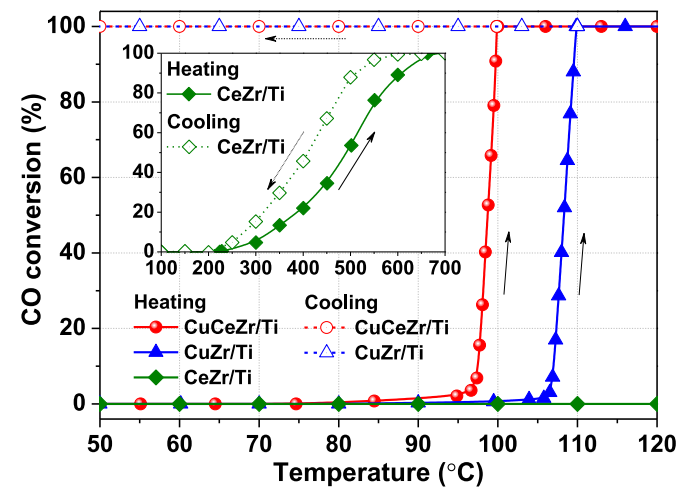

Fig. 6. Temperature-programmed ignition of $\mathrm{CO}$ over catalysts.

$\mathrm{CuCeZr} / \mathrm{Ti}$ show that its $\alpha$-oxygen adsorption capacity is higher than that of $\mathrm{CuZr} / \mathrm{Ti}$, indicating that oxygen is easily activated by $\mathrm{CuCeZr} / \mathrm{Ti}$.

\subsection{Temperature-programmed catalytic ignition of $\mathrm{CO}$}

Before investigating the effects of DBD on $\mathrm{CO}$ catalytic ignition, the activities of $\mathrm{CeZr} / \mathrm{Ti}$, $\mathrm{CuZr} / \mathrm{Ti}$, and $\mathrm{CuCeZr} / \mathrm{Ti}$ were evaluated using TPI tests, with data from the heating and cooling steps in the experiments. The results are shown in Fig. 6. On heating, $\mathrm{CeZr} / \mathrm{Ti}$ is inactive in $\mathrm{CO}$ combustion until the temperature is greater than $228{ }^{\circ} \mathrm{C}$. CO conversion gradually increases with increasing temperature and reaches $100 \%$ at $683{ }^{\circ} \mathrm{C}$. The cooling process occurs at lower temperatures than the corresponding heating process, showing hysteresis, because of exothermic oxidation reactions. For $\mathrm{CuZr} / \mathrm{Ti}$ and $\mathrm{CuCeZr} / \mathrm{Ti}$, significant catalytic ignition can occur at the gas-solid phase interface, giving $\mathrm{CO}$ ignition temperatures $\left(T_{\mathrm{ig}}\right.$, corresponding to $10 \% \mathrm{CO}$ conversion) of 106 and $97{ }^{\circ} \mathrm{C}$, respectively. The high low-temperature 


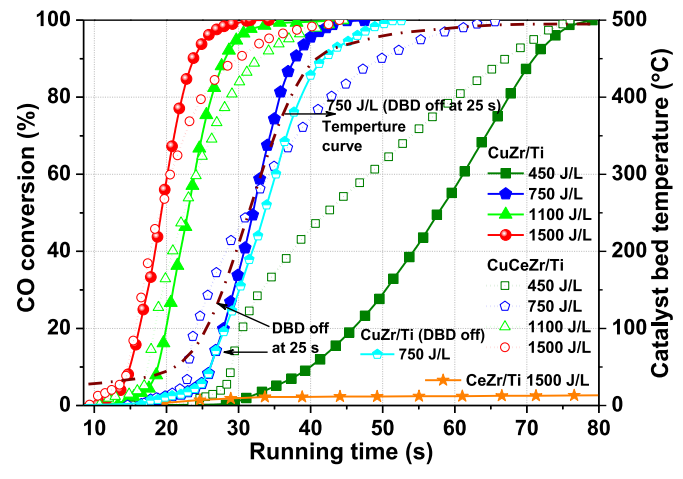

Fig. 7. CO catalytic ignition induced by DBD.

activity over $\mathrm{CuCeZr} / \mathrm{Ti}$ is related to incorporation of some copper ions into cerium oxides and the formation of a $\mathrm{Ce}^{4+} / \mathrm{Ce}^{3+}$ redox couple, which promotes reducibility and facilitates oxygen transport on the catalyst surface (shown by $\mathrm{H}_{2}-\mathrm{TPR}$ and $\mathrm{O}_{2}$-TPD). Under cooling, $100 \% \mathrm{CO}$ conversion can be consistently maintained, even after the controlled temperature decreases to room temperature, i.e., around $25^{\circ} \mathrm{C}$. Fast mass and heat transfer at the gas-solid phase interface clearly promote self-sustained CO catalytic combustion.

\subsection{Catalytic ignition of $C O$ by $D B D$}

Application of an AC voltage to a $\mathrm{CO}+\mathrm{O}_{2} / \mathrm{N}_{2}$ mixture causes electrical breakdown at about $6.5 \mathrm{kV}$ (AC frequency $=10.0 \mathrm{kHz}$, room temperature). Figure 7 shows the effects of DBD on CO catalytic ignition. The supplied voltage was varied to obtain SEDs from 450 to $1500 \mathrm{~J} / \mathrm{L}$, which is similar to that $(0.5-2.0 \mathrm{~kJ} / \mathrm{L})$ of Subrahmanyam et al. [14] and that $(0.2-1.7 \mathrm{~kJ} / \mathrm{L})$ of Kiwi-Minsker et al. [15]. The high SED is employed in the present work in order to shorten the ignition time of $\mathrm{CO}$ catalytic combustion. $\mathrm{CO}$ clearly cannot be ignited by DBD over the CeZr/Ti catalyst, even when the SED is $1500 \mathrm{~J} / \mathrm{L}$, which is very similar to that for TPI. The dissociation energy of $\mathrm{CO}$ molecules is $13.5 \mathrm{eV}$, therefore $\mathrm{CO}$ molecule dissociation is difficult, but they can collide with active oxygen radicals in the gas phase to form small amounts of $\mathrm{CO}_{2}$. The low $\mathrm{CO}$ conversion during discharge does not depend on the temperature and corresponding thermocatalysis, because the $\mathrm{CeZr} / \mathrm{Ti}$ background temperature, which was monitored synchronously (Fig. 8), increased from room temperature to $144{ }^{\circ} \mathrm{C}$ after DBD operation for $80 \mathrm{~s}$. These results strongly suggest that the supported copper catalysts play a dominant role in the DBDassisted ignition of $\mathrm{CO}$. The effects of thermal and plasma catalysis were distinguished by measuring the background temperatures of $\mathrm{CuZr} / \mathrm{Ti}$ and $\mathrm{CuCeZr} / \mathrm{Ti}$ in a $15 \% \mathrm{O}_{2} / \mathrm{N}_{2}$ atmosphere instead of $15 \% \mathrm{CO}+15 \% \mathrm{O}_{2} / \mathrm{N}_{2}$, to avoid runaway induced

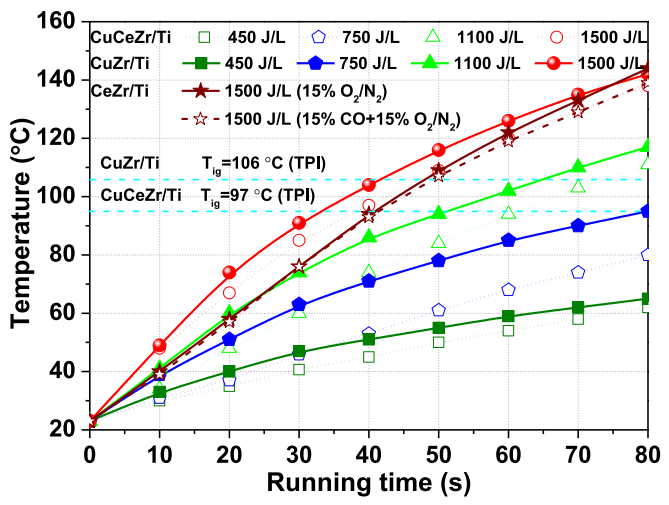

Fig. 8. Background temperature evolution with time as function of DBD. Gas conditions: $15 \% \mathrm{CO}+15 \% \mathrm{O}_{2} / \mathrm{N}_{2}$ and $15 \% \mathrm{O}_{2} / \mathrm{N}_{2}$ for $\mathrm{CeZr} / \mathrm{Ti} ; 15 \% \mathrm{O}_{2} / \mathrm{N}_{2}$ for $\mathrm{CuZr} / \mathrm{Ti}$ and $\mathrm{CeCeZr/Ti}$.

Table 2

Capacitances of dielectric barriers for catalysts during DBD.

\begin{tabular}{lllll}
\hline Sample & \multicolumn{4}{c}{ Capacitance of dielectric barrier (nF) } \\
\cline { 2 - 5 } & $450 \mathrm{~J} / \mathrm{L}$ & $750 \mathrm{~J} / \mathrm{L}$ & $1100 \mathrm{~J} / \mathrm{L}$ & $1500 \mathrm{~J} / \mathrm{L}$ \\
\hline $\mathrm{CeZr} / \mathrm{Ti}$ & 24.7 & 32.6 & 41.7 & 55.3 \\
$\mathrm{CuZr} / \mathrm{Ti}$ & 21.9 & 40.7 & 51.9 & 62.1 \\
$\mathrm{CuCeZr} / \mathrm{Ti}$ & 25.3 & 33.2 & 43.9 & 55.5 \\
\hline
\end{tabular}

by $\mathrm{CO}$ ignition, since the temperature curves obtained for the $\mathrm{CeZr} / \mathrm{Ti}$ has only $5{ }^{\circ} \mathrm{C}$ difference under these two circumstances till the DBD operation at $80 \mathrm{~s}$ (Fig. 8). The current flow induced by the migration of electrons and ions promotes a temperature increase in the reactor through joule heating, dielectric loss, and gas heating in the plasma channel. The temperature rise with time is faster for $\mathrm{CuZr} / \mathrm{Ti}$ than for $\mathrm{CuCeZr} / \mathrm{Ti}$ at the same SED. This behavior can be explained by a higher capacitance of the dielectric barrier for $\mathrm{CuZr} / \mathrm{Ti}$ (Table 2), leading to a higher dielectric loss.

Taking $\mathrm{CuZr} / \mathrm{Ti}$ as an example, when the SED is set at $450 \mathrm{~J} / \mathrm{L}$, micro-discharges are created but a low current density is maintained. In this case, $\mathrm{CO}$ oxidation starts at $29 \mathrm{~s}$ and gradually increases with DBD operating time up to $100 \%$ CO conversion at $79 \mathrm{~s}$ (Fig. 7). An increase in the SED significantly reduces the ignition delay, and two main steps occur during DBD. At an SED of $750 \mathrm{~J} / \mathrm{L}$, the first step can be described as a slow induction process that begins at $18 \mathrm{~s}$ and then continues at a relatively slow rate until $25 \mathrm{~s}$. The reaction rate in this region is controlled by transport of reactants to the active sites on the catalysts [16]. The second step is the ignition process. The oxidation rate at this point is fast enough to induce a strong increase in the local temperature, and then catalytic light-off is propagated because of the evolved reaction heat, even if the DBD is cut off at this stage, as shown in 
Fig. 7, enabling thermal CO combustion. Typical temperature curve of catalyst bed as a function of time, with initiation and cessation of DBD, has also been given in Fig. 7. In this step, the reaction rate is controlled by external diffusion [17]. Kirkpatrick et al. [18] showed that the plasma generated upstream of the catalyst gave a thermal "push" to the catalyst when it was near its light-off temperature. Because of the low concentration of $\mathrm{CO}(0.45 \%)$, however, thermochemical runaway did not occur on the catalyst surface. Therefore, only $23 \% \mathrm{CO}$ conversion was achieved. A combination of the results in Figs. 7 and 8 shows that DBD-assisted catalytic ignition occurs at $27 \mathrm{~s}$ (ignition time $t_{\mathrm{ig}}$, determined at $10 \% \mathrm{CO}$ conversion), corresponding to a background temperature of $60^{\circ} \mathrm{C}$, which is significantly lower than the $T_{\text {ig }}\left(97^{\circ} \mathrm{C}\right)$ for thermal catalysis. These results indicate that plasma generates reactive radicals and excited molecules, which may contribute to $\mathrm{CO}$ catalytic ignition. At the same SED, the induction process occurs earlier with $\mathrm{CuCeZr} / \mathrm{Ti}$ than with $\mathrm{CuZr} / \mathrm{Ti}$, with $t_{\mathrm{ig}}$ values of 23 , 17, and $14 \mathrm{~s}$ for $\mathrm{CuCeZr} / \mathrm{Ti}$ at SEDs of 750,1100 , and $1500 \mathrm{~J} / \mathrm{L}$, respectively. The ignition curves for the second step, however, show that the increases in $\mathrm{CO}$ conversion over $\mathrm{CuCeZr} / \mathrm{Ti}$ are slower (the slopes are less steep) than those over $\mathrm{CuZr} / \mathrm{Ti}$. The ignition curves for $\mathrm{CuZr} / \mathrm{Ti}$ cross with those for $\mathrm{CuCeZr} / \mathrm{Ti}$ at 33, 24, and $20 \mathrm{~s}$ at SEDs of 750, 1100, and $1500 \mathrm{~J} / \mathrm{L}$ respectively, and $100 \% \mathrm{CO}$ conversion is achieved at 47,42 , and $34 \mathrm{~s}$, respectively, which shortens the ignition delay. In DBD ignition, $\mathrm{CO}_{2}$ is the only product and no other byproducts can be detected.

\subsection{Active species generated during $D B D$}

The plasma species present in the DBD discharge were identified from global optical emission spectra recorded in pure $\mathrm{N}_{2}, \mathrm{O}_{2}, \mathrm{CO}$, and $15 \% \mathrm{CO}+15 \% \mathrm{O}_{2} / \mathrm{N}_{2}$ discharges. The spectra are shown in Fig. 9. In a pure $\mathrm{N}_{2}$ atmosphere, the main emission peaks in the range $200-390 \mathrm{~nm}$ are the $\mathrm{N}_{2}$ second positive system $\left(\mathrm{C}^{3} \Pi_{\mathrm{u}}-\mathrm{B}^{3} \Pi_{\mathrm{g}}\right)$. In a pure $\mathrm{O}_{2}$ discharge, $\mathrm{O}$ is not detected. The $\mathrm{N}_{2}{ }^{*}$ emission spectrum arises from gas breakdown outside the reactor. Although the high-energy electrons in DBD can dissociate oxygen molecules into atoms, ozone formation consumes oxygen atoms, e.g., $\mathrm{O}\left({ }^{3} \mathrm{P}\right)$ and $\mathrm{O}\left({ }^{1} \mathrm{D}\right)$. In the DBD spectrum of $\mathrm{CO}$, the Angstrom $\left(\mathrm{B}^{1} \Sigma^{+}-\mathrm{A}^{1} \Pi\right)$ ro-vibrational system appears in the range $515-590 \mathrm{~nm}$, corresponding to highly excited electronic states of CO [19]. For DBD of the $\mathrm{CO}+\mathrm{O}_{2} / \mathrm{N}_{2}$ mixture, the spectral lines of $\mathrm{N}_{2}$ molecules are more intense than those of other species, because $\mathrm{N}_{2}$ accounts for $70 \%$ of the gas mixture. The presence of $\mathrm{N}_{2}$ results in a decrease in the $\mathrm{CO}$ excitation rate, but some excited $\mathrm{N}_{2}{ }^{*}$ can collide with $\mathrm{O}_{2}$ to produce oxygen atoms. This is comparable to $\mathrm{O}_{2}$ dissociation by collisions with electrons, and results in a higher den-

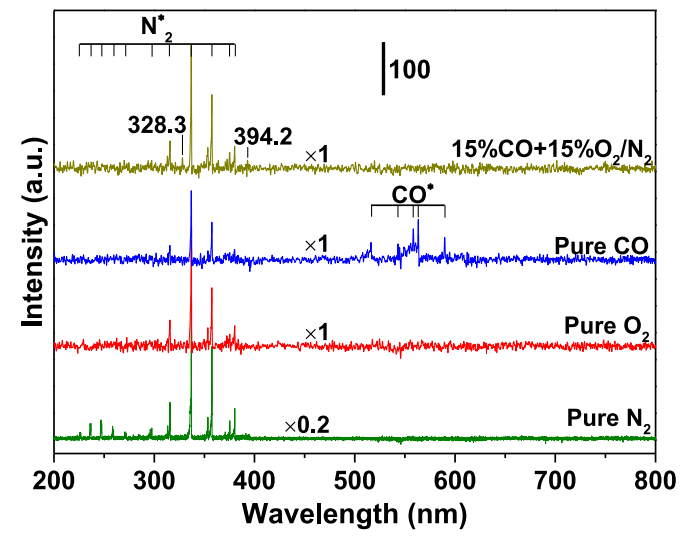

Fig. 9. Optical emission spectra of DBD over $\mathrm{CeZr} / \mathrm{Ti}$ at SED of $1500 \mathrm{~J} / \mathrm{L}$.

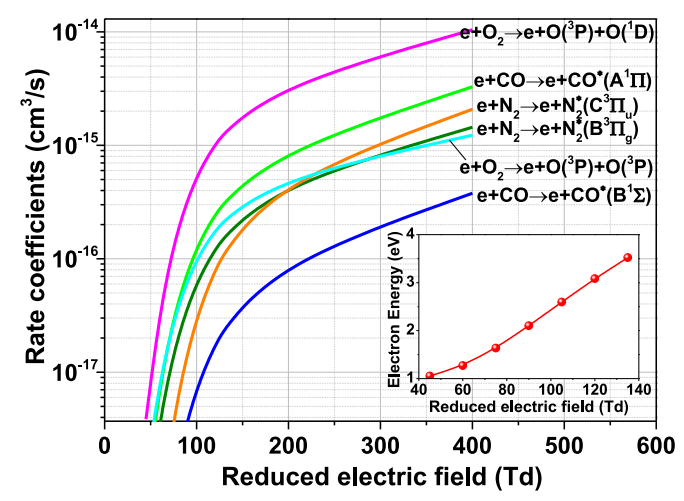

Fig. 10. Rate coefficients of active species formed by direct impact with electrons.

sity of oxygen atoms ( 328.3 and $394.2 \mathrm{~nm}$ ) than that in a pure $\mathrm{O}_{2}$ atmosphere. The rate coefficients for electron-impact dissociations and excitations of $\mathrm{N}_{2}, \mathrm{O}_{2}$, and $\mathrm{CO}$ were calculated based on the electron Boltzmann equation using the standard BOLSIG+ code and the cross-section from the Phelps database [20]. For given discharge conditions (SED of $450-1500 \mathrm{~J} / \mathrm{L}$ ), the reduced electric field ratio $E / N$ (where $E$ is the electric field strength and $N$ is the number of neutral particles) varies from 45 to $135 \mathrm{Td}$, corresponding to a mean electron energy of 1.1 to $3.5 \mathrm{eV}$, as shown in Fig. 10. It can be clearly seen that the most efficient channel is dissociation with production of ground-state $\mathrm{O}\left({ }^{3} \mathrm{P}\right)$ and excited $\mathrm{O}\left({ }^{1} \mathrm{D}\right)$ atoms. The formation rate coefficients of the active species decrease in the sequence: $\mathrm{O}\left({ }^{3} \mathrm{P}\right)>\mathrm{O}\left({ }^{1} \mathrm{D}\right)>\mathrm{CO}^{*}\left(\mathrm{~A}^{1} \Pi\right)$ $>\mathrm{N}_{2} *\left(\mathrm{~B}^{3} \Pi_{\mathrm{g}}\right)>\mathrm{N}_{2} *\left(\mathrm{~B}^{3} \Pi_{\mathrm{g}}\right)>\mathrm{CO}^{*}\left(\mathrm{~B}^{1} \Pi\right)$. Such active species formed by DBD can promote $\mathrm{CO}$ catalytic ignition. 


\subsection{Proposed reaction mechanism}

$\mathrm{CO}$ catalytic ignition on $\mathrm{CuZr} / \mathrm{Ti}$ and $\mathrm{CuCeZr}$ /Ti proceeds via a Langmuir-Hinshelwood mechanism, in both plasma and thermal catalysis. During TPI, CO is adsorbed on copper sites in the induction step to yield $\mathrm{Cu}^{+}$-carbonyls, and gaseous $\mathrm{O}_{2}$ is adsorbed on either copper sites or oxygen vacancies in the mixed oxides. In these competitive adsorption processes, $\mathrm{CO}$ adsorption is favored, therefore the reaction is self-poisoned by $\mathrm{CO}$ [17]. The critical amount of adsorbed $\mathrm{CO}$ can be reached by increasing the temperature to shift the adsorption/desorption equilibrium toward oxygen desorption. At this point, some adsorbed $\mathrm{CO}$ also interacts with adsorbed oxygen atoms in a slow exothermic reaction that results in gaseous $\mathrm{CO}_{2}$ formation and release. When the system is ignited by increasing the temperature, all the adsorbed $\mathrm{CO}$ immediately reacts rapidly, and sufficient free adsorption sites are generated frequently for CO adsorption. During DBD, the discharge excites some of the $\mathrm{CO}$ molecules and dissociates $\mathrm{O}_{2}$ molecules into oxygen atoms in the gas phase before adsorption. Given that the molecules delivered to the catalyst surface are already excited or dissociated, the adsorption step is easier, leading to induction beginning at a lower background temperature than in thermal catalysis. At this stage, plasma catalysis is dominant. At the same SED, induction with $\mathrm{CuCeZr} / \mathrm{Ti}$ begins earlier than that with $\mathrm{CuZr} / \mathrm{Ti}$. This is in good agreement with the reducibilities and oxygen-transfer properties of these catalysts. The superiority of $\mathrm{CuCeZr} / \mathrm{Ti}$ is maintained until the ignition process begins. The $\mathrm{CO}$ oxidation rate is fast enough to induce a strong increase in the local temperature, which accelerates external diffusion and mass transfer, based on the gas diffusivity $D_{\mathrm{v}} \propto T^{1.81}$ and the mass-transfer coefficient $K_{\mathrm{s}}=$ $\left(D_{\mathrm{v}} S\right)^{1 / 2}$, where $T$ is temperature and $S$ denotes the update frequency [21]. In this step, external diffusion (thermal catalysis) is dominant. Because more $\mathrm{CO}$ adsorption sites can be provided by $\mathrm{CuZr} / \mathrm{Ti}$ than by $\mathrm{CuCeZr} / \mathrm{Ti}$, which is beneficial for external diffusion and mass transfer, the ignition curves for $\mathrm{CuZr} / \mathrm{Ti}$ cross those for $\mathrm{CuCeZr} / \mathrm{Ti}$, contributing to shortening of the ignition delay.

\section{Conclusion}

We investigated DBD-ignited self-sustained $\mathrm{CO}$ combustion over $\mathrm{CeZr} / \mathrm{Ti}, \mathrm{CuZr} / \mathrm{Ti}$, and $\mathrm{CuCeZr/Ti}$ catalysts, combined with TPI. DBD ignition gave rapid start-up and evolved in two steps. The induction process was dominated by plasma catalysis. Because of the higher reducibility and oxygen-transfer ability of $\mathrm{CuCeZr} / \mathrm{Ti}$, induction was earlier with this catalyst than with $\mathrm{CuZr} / \mathrm{Ti}$, the ignition process was governed by thermal catalysis. $\mathrm{CuZr} / \mathrm{Ti}$ provided more $\mathrm{CO}$ adsorption sites than did $\mathrm{CuCeZr} / \mathrm{Ti}$, and this helped to shorten the ignition delay.

\section{Acknowledgment}

This work is financially supported by the $\mathrm{Na}$ tional Natural Science Found of China (No. 21307088). The work is also supported by State Key Laboratory of Engines, Tianjin University (K20148).

\section{References}

[1] S. Li, X.L. Wei, L.X. Yu, Fuel 90 (2011) 1350-1360.

[2] J.E. Abboud, N. Jiang, Z. Zhang, S. Roy, J.R. Gord, Combust. Flame 160 (2013) 1842-1847.

[3] S. Nagaraja, W. Sun, V. Yang, Proc. Combust. Inst. 35 (2015) 3497-3504.

[4] X. Zhang, M.S. Cha, Proc. Combust. Inst. 35 (2015) 3447-3454.

[5] E. Mintusov, A. Serdyuchenko, I. Choi, Proc. Combust. Inst. 32 (2009) 3181-3188.

[6] S. Jo, D.H. Lee, Y.-H Song, Int. J. Hydrog. Energy 38 (2013) 13643-13648.

[7] S. Li, Q. Hao, R. Zhao, D. Liu, H. Duan, B. Dou, Chem. Eng. J. 71 (2013) 939-944.

[8] B. Dou, F. Bin, C. Wang, Q Jia, J. Li, J. Electrostat. 71 (2013) 939-944.

[9] P. Gaudin, S. Dorge, H. Nouali, et al., Appl. Catal. A: Gen. 504 (2015) 110-118.

[10] Q. Wan, L. Duan, K. He, J. Li, Chem. Eng. J. 170 (2011) 512-517.

[11] R. Zhang, W.Y. Teoh, R. Amal, B. Chen, S. Kaliaguine, J. Catal. 272 (2010) 210-219.

[12] D. Gamarra, A. Martínez-Arias, J. Catal. 263 (2009) 189-195.

[13] Y. Yu, Q. Zhong, W. Cai, J. Ding, J. Mol. Catal. A: Chem. 398 (2015) 344-352.

[14] S. Mahammadunnisa, P. Manoj Kumar Reddy, E. Linga Reddy, C. Subrahmanyam, Catal. Today 211 (2013) 53-57.

[15] C. Subrahmanyam, A. Renken, L. Kiwi-Minsker, Appl. Catal. B: Environ. 65 (2006) 157-162.

[16] K. Arnby, A. Törncrona, B. Andersson, M. Skoglundh, J. Catal. 272 (2004) 252-261.

[17] P.-A Carlsson, M. Skoglundh, Appl. Catal. B: Environ. 101 (2011) 669-675.

[18] M.J. Kirkpatrick, E. Odic, S. Zinola, J. Lavyb, Appl. Catal. B: Environ. (2012) 1-9.

[19] R. Geiger, D. Staack, J. Phys. D: Appl. Phys. 44 (2015) 274005

[20] Plasma Data Exchange Project, Phelps database, www.lxcat.net.

[21] W. L.Mccabe, J. C.Smith, Peter Harriott, Unit Oper, Chem. Eng. (1993). 